\title{
Managing risks from pests in global commodity networks - policy perspectives
}

\author{
Julie Flood $^{1} \cdot$ Roger Day ${ }^{2}$
}

Received: 29 September 2015 / Accepted: 18 November 2015 / Published online: 8 December 2015

(C) The Author(s) 2015. This article is published with open access at Springerlink.com

\begin{abstract}
Up to $80 \%$ of global commodity production comes from smallholdings of less than 0.5 ha. Yet commodity crops may be a substantial proportion of a country's exports, and feed into global supply networks. Pest risks thus have consequences at local, national and global levels. We consider three categories of risk in global commodity networks: introduction of pests to new areas, upsurges of established pests and the risks arising from management efforts. In each category we provide case studies and examples, and consider policy options. Increased travel, trade and transport increase the risks of introduction. Commodity specific biosecurity plans are required for preventing introductions, including analysis of the specific risks (pest pathways) and preparation of emergency responses. Regional and international cooperation is essential. Upsurges can be caused by crop management, evolution of new strains, and environment change. National systems must be responsive to detect problems and address them quickly. Capacity building for surveillance and diagnostics, and the development and dissemination of integrated pest management methods are needed. Investment in research and extension for the agricultural sector is vital. Risks linked with management efforts, specifically, the risk from agrochemicals are considered. Concerns in developed countries over food safety and environmental damage can place constraints on pest management. Failure to comply leads to loss of markets and buyer confidence. Policies that favour lower-risk pest management methods are needed, but are often lacking.
\end{abstract}

Julie Flood

j.flood@cabi.org

CABI E-UK, Bakeham Lane, Egham, Surrey TW209TY, UK

2 CABI Africa, P.O. Box 633-00621, Nairobi, Kenya
Keywords Biosecurity $\cdot$ Coffee $\cdot$ Cocoa $\cdot$ Plant pathogens

\section{Introduction}

Many of our trans-global supply chains for agricultural commodities are products of the colonial era of trade where raw materials were produced in one part of the world and shipped to other parts, where they were converted, or manufactured into added-value goods and consumed. These traded raw materials now form the basis of multi-billion dollar global industries. Coffee is the most valuable tropical agricultural commodity representing over US\$22 billion of global trade in 2012 with an estimated 1.6 billion cups of coffee consumed every day. One characteristic of such commodity production is a complex supply chain involving interactions of many players including producers, buyers, traders, "middle men", processors, shippers, manufacturers, retailers and consumers (Gilmour 2004) as well as associated stakeholders such as Agri-dealers, the financial service sector, legislators and other policy makers. Although called "supply chains" they are more like networks of inter-dependent players each with multiple links. At the consumption end of the networks these commodities are part of developed countries' "high-consuming lifestyles" while at the other end are producers who often struggle to make a livelihood.

Risk and risk management in such networks thus means very different things to different people, and our focus here is on the risks presented by pests, particularly from the producers' viewpoint. Up to $80 \%$ of global commodity production typically comes from smallholdings of less than 0.5 ha. The producers may have little or no land tenure, often use few inputs, and rely on their own labour. Often there is little "value added" in the countries of production, and low farm gate prices, coupled with "boom and bust cycles" where, if 
commodity prices increase even marginally, producers plant more of that crop only to be rewarded with lower prices as market forces intervene. These factors combine to increase uncertainty for producers. Such uncertainty reduces the expected returns on investment in crop management activities such as pest management, so amplifying the risks.

Related to financial uncertainties are a number of other risks. These include climatic risks that can affect yield, supply and price and physical risks such as theft, which can reduce the quantity of saleable goods. Some of the greatest risks to commodity production are from pests; for example a recent analysis of risk in Ghana's cocoa supply chain concluded that three of the top five risks are pests, the other two being price volatility and smuggling of crop both to and from Cote d'Ivoire (World Bank 2012).

Risk is the likelihood of something (usually unwanted) happening, multiplied by the consequence if it does. In this paper, three categories of risk in global commodity networks are considered: the introduction of pests into areas where they previously did not occur; upsurges or outbreaks of established pests; and risks arising from management efforts, particularly the use of pesticides. For each category of risk we provide case studies and examples, particularly to illustrate the consequences or impact associated with the risks, but also to show how risks can be managed, and the consequences reduced. A pest is defined here as any species, strain or biotype of plant, animal or pathogenic agent injurious to plants or plant products (FAO 2009).

\section{Risks of introduced pests}

The risk of pests being introduced to areas outside their natural range has long been recognised. The catastrophic invasion of European vineyards by the American vine louse (Viteus vitifolii) prompted an international agreement in 1878, though not until 1951 was the International Plant Protection Convention established that aims to prevent the spread and introduction of all plant pests (MacLeod et al. 2010). The probability of pests being introduced by natural means is generally low, although climate change is likely to affect this. However, of far greater importance is the vast amount of global trade, travel, transport and tourism that now occurs, and this has greatly increased the likelihood of pests being introduced (Perrings et al. 2000; Pimentel 2011).

Not all species introduced to a new area can survive, not all become established, and not all of those that establish become pests. A rule of thumb is that the probability is 0.1 at each stage (Williamson and Fitter 1996). However, those species that do become pests can have major consequences, partly because they often leave behind their natural controls. For example, Coffee Berry Borer (CBB) originated in Africa but has spread to all coffee producing countries with the exception of Papua New Guinea. It is estimated to cause about $\$ 0.5 \mathrm{bn}$ losses annually (http://journals.plos.org/plosone/article?id= 10.1371/journal.pone.0024528). Similarly Coffee Leaf Rust (CLR) also originated in Africa but has spread to all coffee producing areas. In contrast for cocoa, there is currently a regional distribution of pests (Table 1) which presents risks of introduction into pest free areas. The two case studies below provide examples of cocoa pests that have moved beyond their natural range.

\section{Case study 1: introduction of witches' broom into cocoa producing countries of south and central America}

Witches' broom (Moniliophthora perniciosa) is perhaps the oldest known cocoa disease (Flood and Murphy 2004) and is thought to have co-evolved with cocoa. It is endemic in the forests of the Amazon and Orinoco basins and probably moved from these isolated foci to cocoa plantations. The basidiospore is the only naturally infective propagule (Evans 1981). Production of spore producing bodies (basidiocarps) is dependent on complex interactions between host and the environment and requires periods of wet and dry weather. The conditions which enable basidiocarp production and subsequent spore release are also those which encourage the flush of growth in the cocoa, thus synchronizing spore release with the presence of multiple infection sites. Destruction of the beans inside infected pods are easily observed (Fig. 1).

\section{Impact}

The introduction of WB in Surinam (1895) and Guyana (1906) led to the decline of the cocoa industry and eventual abandonment. The disease arrived in Bahia 1989 and Brazilian production fell from nearly 400,000 tonnes prior to the introduction to 150,000 tonnes 10 years later (Flood and Murphy 2004). Brazil became a net importer of cocoa as opposed to being the second biggest producer. Over the last century, the pathogen has spread throughout the cocoa-growing regions of South America, into Panama and the Caribbean; this spread has led to successive disasters and gives a foretaste of its destructive power should it be introduced into other cocoa producing countries. West Africa, the biggest producer of cocoa, is particularly vulnerable should the pathogen be introduced given the susceptible germplasm grown and the small holder farming system. The pest is currently confined to the Americas but ranked second in terms of percentage global loss of cocoa (18\%). 
Table 1 Distribution of the world's major cocoa pests

\begin{tabular}{|c|c|c|c|c|}
\hline Pest & South America & Central America & West Africa & South East Asia \\
\hline Cocoa pod borer (Conopomorpha cramerella) & & & & $\checkmark$ (native) \\
\hline Vascular streak die-back (Oncobasidium theobromae & & & & $\sqrt{ }($ native $)$ \\
\hline Black pod (Phytophthora megakarya) & & & $\checkmark$ (native) & \\
\hline Black pod (Phytophthora palmivora) & $\checkmark($ global $)$ & $\sqrt{ }($ global $)$ & $\checkmark($ global $)$ & $\checkmark($ global $)$ \\
\hline Swollen shoot & & & $\checkmark$ (native) & \\
\hline Mirids (S. singularis and D. theobromae) & & & $\checkmark$ (native) & \\
\hline Witches' broom (Moniliophthora perniciosa) & $\checkmark$ (native) & $\checkmark$ (introduced) & & \\
\hline Frosty Pod Rot (Moniliophthora roreri) & $\checkmark$ (native) & $\checkmark$ (introduced) & & \\
\hline
\end{tabular}

\section{Management}

Although the pest was present in the Amazon, in an attempt to exclude it from the highly productive cocoa growing areas in Bahia, the Brazilian authorities were very active in reducing the risk of introduction. Since 1978, a cordon sanitaire had been initiated to avoid disease spread from endemic areas to Bahia. This exclusion policy was highly successful for a

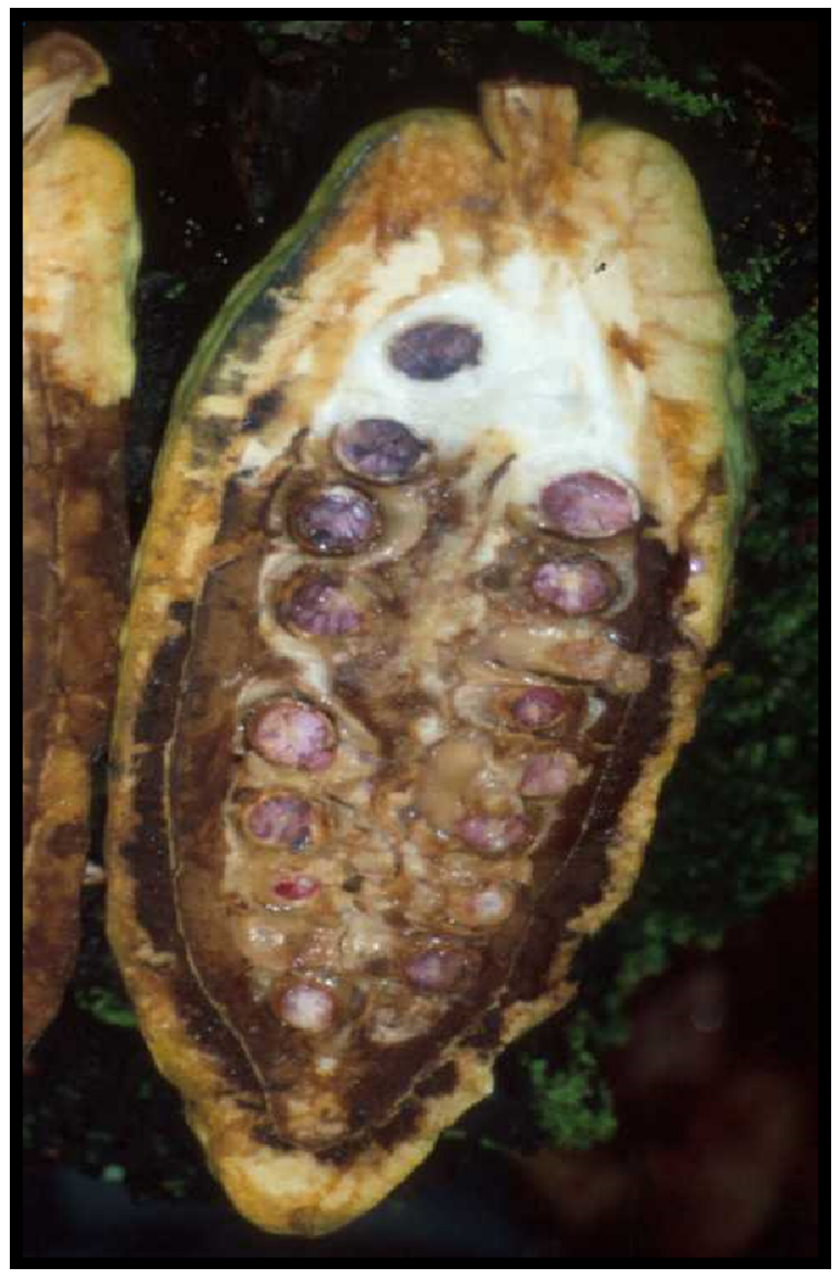

Fig. 1 Destruction of cocoa beans inside a cocoa pod following infection with Witches'broom (Moniliophthora perniciosa) number of years. Quarantine posts were placed on routes (road, sea and air) into Bahia. A post-entry plant quarantine station was sited at Salvador, Bahia, to ensure only disease free material was released. Research on management of the disease was conducted in endemic areas. Similarly, when WB spread into Panama, from Colombia in the late 1980s and the whole of Central American cocoa production was threatened, swift action created another phyto-sanitary cordon. This barrier has remained effective and Central America has remained free from the disease up to the present time.

This action illustrates what can be achieved when there is political will and co-operation, government and institutional willingness and a co-ordinated approach. Nevertheless, despite its continuing effectiveness, vigilance is needed. Should the phytosanitary barrier in Panama be breached, the disease is again likely to move quickly north, adding to the destruction already inflicted by Frosty Pod Rot (FP). Also, the geography of the region has helped as the isthmus of Central America is a relatively narrow strip of land, thus facilitating the setting up of such a cordon. This would not be the case if the pathogen were to spread to West Africa and thus, strict adherence to guidelines on safe movement of cocoa germplasm (End et al. 2014) is paramount to prevent the further spread of WB worldwide, and the preparation of contingency plans for rapid deployment in the event that it does.

In 1989, despite the cordon sanitaire being successful within Brazil over a number of years, several outbreaks occurred in Bahia (Pereira et al. 1990). Exclusion was now not an option. Multiple infection foci were reported and together with the fact that the pathogen was unlikely to have spread naturally via prevailing winds, or that spore life is around $4 \mathrm{~h}$ and diseased material was found along river banks, it was concluded that human mediated spread had occurred (Periera et al.1996). Eradication was attempted; phyto-sanitation (removal of infected trees) coupled with chemical control including at some stages aerial spraying of fungicides. Destruction of cocoa trees followed in an attempt to limit spread but widespread use of herbicides attracted considerable criticism from environmentalists. Eradication was not successful and the disease continued to spread (Pereira et al. 1996). The policy then 
changed from eradication to one of ongoing management which remains ongoing and includes phyto-sanitation, breeding for resistance, capacity building with the producers to both diagnose and manage the disease and more recently biocontrol "Trichovab". The Brazilian government has also invested heavily in the infrastructure of the region including modernization and rehabilitation of abandoned farms, modernization of the grinding industry and improved commercial opportunities in urban areas to cope with producers leaving rural areas. Nevertheless, the disease remains a serious constraint. Pereira recorded losses of 250,000 tonnes due to WB in 2001 (cited in Pereira 2012). Management costs are high - sanitation alone has been estimated at between 150 and 460 US\$ per hectare per annum in Bahia (Martins 2006) which would make it impossible for smallholder farmers in West Africa to manage the disease.

\section{Case study 2: introduction of frosty pod rot into cocoa producing countries of central and South America}

Another serious pest of Theobroma and the closely related genus, Herrania is Frosty Pod Rot (Moniliophthora roreri). Theobroma gileri, rather than cocoa, is considered to be the indigenous forest host. FP probably moved from the submontane forests of the western Andes of Ecuador and Colombia, where T. gileri is found, into the cocoa plantations of western Ecuador and Colombia in the 19th century. The pest infects only actively growing pod tissues and flower cushions. The lag between infection and appearance of symptoms is usually $1-3$ months. This lag phase can have serious implications for quarantine (Flood and Murphy 2004).

The 'frosty' covering on diseased pods (Fig. 2) is suggested to be the products of genetic re-combination, rather than asexual conidia as had been supposed. This genetic variability, coupled with the enormous spore production (44 million spores per $\mathrm{cm}^{2}$ pod surface), endows the fungus with considerable adaptability). Such variability has enabled it to overcome resistance in most cocoa cultivars and to infect all the Theobroma and Herrania species so far encountered. For this reason, it is a major threat to global cocoa production. Thick walls allow the spores to survive for extended periods, such as over a dry season. Viable spores are released from mummified pods after 9 months, an efficient means of seasonal or intercrop carry-over. The dry, powdery nature of the spores means they are readily dislodged in a cloud by water, wind or physical disturbance of the pod, and are easily dispersed up to $1 \mathrm{~km}$ by convection or air currents but the main threat for long distance dispersal is humans.

Anecdotal evidence suggests that the disease first appeared on cocoa in Colombia in 1851 and has spread to many countries in Central and South America (Flood and Murphy 2004).

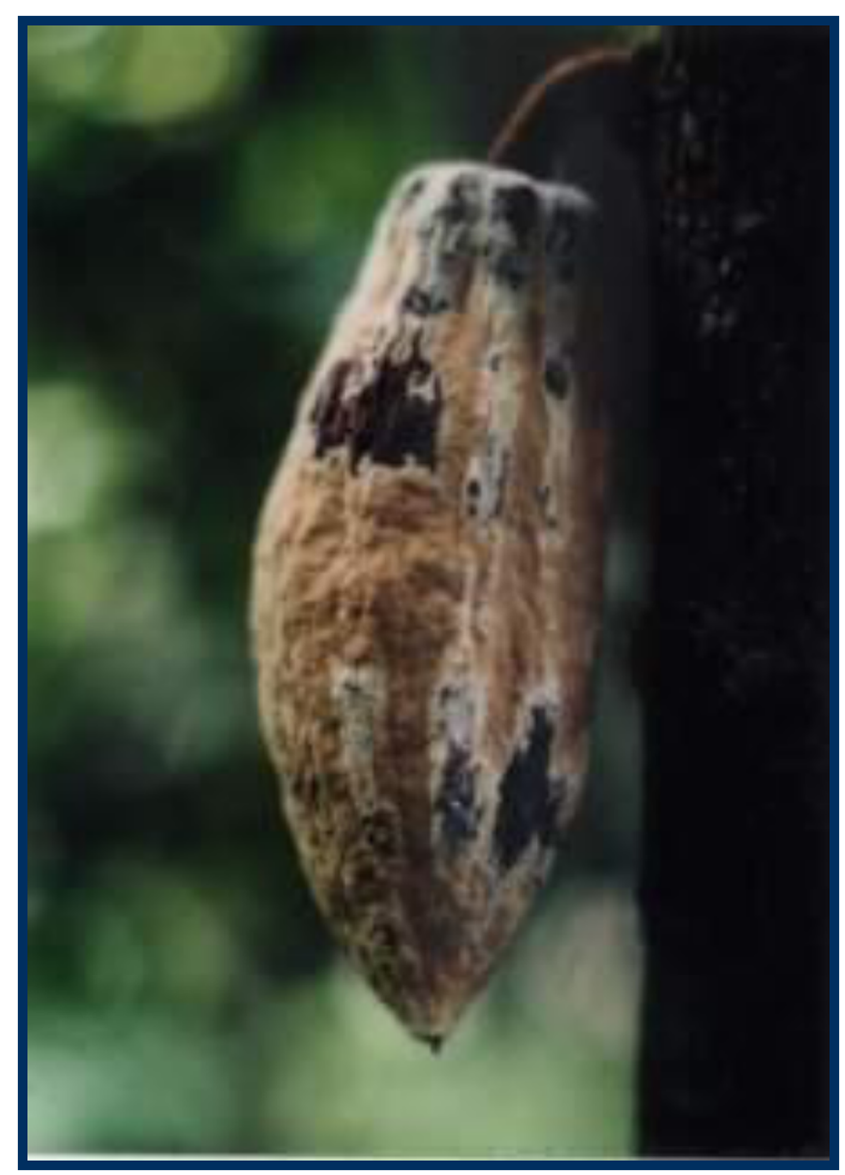

Fig. 2 Symptoms of Frosty Pod Rot (Moniliophthora roreri) on the outside of an infected cocoa pod

The pest has spread $1900 \mathrm{~km}$ in 49 years (Bissesser 2011) and although its introduction into Northern Nicaragua and Honduras was most likely via flooding (dissemination by water), in the majority of introductions, human mediated spread has occurred (Phillips-Mora et al. 2007). Much of this is due to ignorance of the pest and the impact of its introduction. Spread of the pest has been facilitated by the highly susceptible material grown, the cryptic nature of the pest in the early stages and wild hosts that can act as reservoirs of infection. The pest has now spread rapidly down the eastern side of the Andes and threatens Brazilian production just as WB is being effectively managed.

Further expansion in Central America and Venezuela, jeopardises cocoa production in the Caribbean. This is particularly important to Trinidad as it holds one of the International Cocoa Germplasm collections. In response to Caribbean concerns, Bissessar (2011) undertook a risk assessment of the likely introduction of the pest into Trinidad and Tobago from Venezuela and concluded it would not be possible for the fungal spores to be carried from an infected plantation in Venezuela to Trinidad. This is further borne out by an examination of the wind direction distribution for Trinidad. However, because all attempts to eradicate this pest have thus 
far failed and management is extremely costly, Bissessar reiterated that exclusion of the pest remains the most appropriate option for the Caribbean and that means restricting human mediated introduction. He proposed major efforts should be made to strengthen quarantine measures in Venezuela and to educate farmers/processors/public about the risks of moving pods from affected areas. He also suggested a comprehensive biosecurity review of the operation of the Research Division's Cocoa Unit and the International Cocoa Genebank in Trinidad. This included production of adequate propagative material for farmers to reduce the chance of them seeking material elsewhere. With regard to the safe movement of germplasm, the updated guidelines (End et al. 2014) need to be enforced but the greater likely risk of introduction is via informal and often illegal activities. Movement of narcotics and food products are now common between Venezuela and its neighbours including into Southern Trinidad. This is a major weak point in preventing introduction of the pest into Trinidad. Further, direct flights are also increasingly available between Venezuela and the Caribbean.

\section{Impact}

The appearance of FP has been catastrophic to cocoa production in every country to which it has been introduced and it has rapidly replaced WB as the number one constraint in any country where both exist. The disease arrived in Costa Rica in 1978 and by 1983, production had fallen by $72 \%$, with exports decreasing by $96 \%$, resulting in the abandonment of many cocoa farms. FP currently accounts for only approximately $5 \%$ of cocoa losses globally - a relatively low figure due to its restricted distribution. It successfully breached the cordon sanitaire that has been effective for WB. As more cocoa producing countries in Central America become affected by this pathogen, there is a greater chance of the disease reaching the Caribbean islands. Should this pest arrive in West Africa, the social and economic impact would be enormous.

\section{Management}

Some genotypes, which form pods mainly during dry periods when conditions are unfavourable for the pathogen, escape disease. Resistant genotypes could provide a more durable and less costly means of management that could be used to complement other management approaches. A regional breeding programme at the Tropical Agricultural Research and Higher Education Centre (CATIE) in Costa Rica has focused on the identification of resistant material. The program has made significant progress toward developing germplasm with a suitable combination of desirable properties, in particular resistance to $M$. roreri and high yields (Phillips-Mora et al. 2009). The first selected clones were to be released for farmers use in 2007 and multi-location trials were established in Central America in 2008 to test the performance of 20 new promising CATIE selections under different environmental conditions. Thus far, this improved germplasm is performing well.

The other main method for management remains crop sanitation, involving regular removal of infected pods. Crop sanitation must take into account the cryptic nature of the pathogen where apparently healthy pods can become inoculum sources within a few days. However, as the spores can move long distances, disease pressure will remain high unless sanitation efforts are coordinated on a regional scale and this requires regional co-operation and collaboration. Copper fungicides can be effective ( 5 sprays per season reported as cost effective at least in Costa Rica). Spray applications of endophytic Trichoderma have also shown encouraging results in the field. An integrated approach using resistant germplasm, appropriate fungicide sprays, compatible biocontrol and other IPM measures such as good canopy management is probably the way forward.

\section{Summing up policy perspectives on introduced pests}

As the arrival of a new pest is a relatively rare event, it is sometimes difficult to persuade decision makers to allocate the necessary resources to reduce the probability of further arrivals, except where, as in our case studies, there is a known serious pest that is in a neighbouring region, and the consequences are clearly visible. Where possible, preventing introduction of a pest is the most cost effective response, followed by early detection and eradication if it does arrive. As our case studies show, once a new pest has become established, it can cause serious losses on a continuing basis and is extremely costly.

Thus a pre-emptive approach to establish appropriate structures and instruments enabling stakeholders to put in place measures to contain and/or eradicate new pest incursions is needed. This requires an analysis of the risks of pest threats, including the possible pathways for their introduction, establishment and spread (FAO 2013a) and should be coupled with risk-based surveillance for early detection (FAO 1997). A raised level of industry preparedness for emergency response to incursions is the basis of a contingency plan, and in some places industry-wide biosecurity plans are being prepared such as in the oil palm industry in Malaysia. Biosecurity is defined as a set of preventive measures designed to reduce the risk of transmission of infectious diseases of crops and livestock, quarantined pests and living modified organisms (Koblenz 2010). A biosecurity plan should spell out who has what responsibilities, and critically who pays, so that when an emergency arises, there is no delay in making such decisions (Fraser in press, this volume). In addition to national sectoral approaches to biosecurity, regional sectoral biosecurity is also 
needed. On large continents such as Africa, introduction to one country usually means that all countries in the region will end up being affected so a co-ordinated response is needed. Further, in many developing countries where these commodity crops are produced, there is often very limited capacity to implement the action needed, either at national or regional level. This increases the risk, as the consequences are likely to be greater for any pest that arrives.

One pathway for pest introduction is through germplasm movement, so it is essential that this is well regulated. Capacity to undertake pest risk analysis and identify and implement risk management procedures is essential, and guidelines are available for the movement of germplasm of some commodity crops, such as cocoa (End et al. 2014). Informal introductions are harder to regulate, so awareness of the potential threats and exclusion policies to contain them are needed for the whole commodity sector and for the public in general.

\section{Risks of outbreaks or upsurges of established pests}

The next category of pest risk is an upsurge or outbreak of an established pest and two case studies from coffee are used as examples, one from Central America (Coffee Leaf Rust) and one from Africa, (Coffee Wilt Disease). These are established pests that may require regular management, but when upsurges or outbreaks occur a more intensive management regime is needed. In some cases they were once "introduced pests", but having established and spread, eradication is no longer feasible.

Upsurges or outbreaks may be caused by a range of factors, including particular weather patterns, changes in land use, and management practices. Although some crops may have fewer pests than others, every crop has a range of pests that can become serious under the right conditions. Some major pests are almost always damaging, and thus present a very high risk having both a high probability of occurrence and serious consequences.

\section{Case study 1: outbreak of coffee leaf rust in south and central America}

Coffee Leaf Rust (CLR) caused by the fungus Hemileia vastatrix is a major constraint to coffee production world-wide and has been studied for 130 years. Initially, the disease is observed as yellow pustules $(>0.1 \mathrm{~mm}$ in diameter) on the underside of coffee leaves (Fig. 3). Young lesions appear as chlorotic or pale yellow spots some millimetres in diameter and symptoms rapidly progress to defoliation which has a direct effect on coffee yields. In severe cases, the coffee tree is killed. The life-cycle begins with the germination of

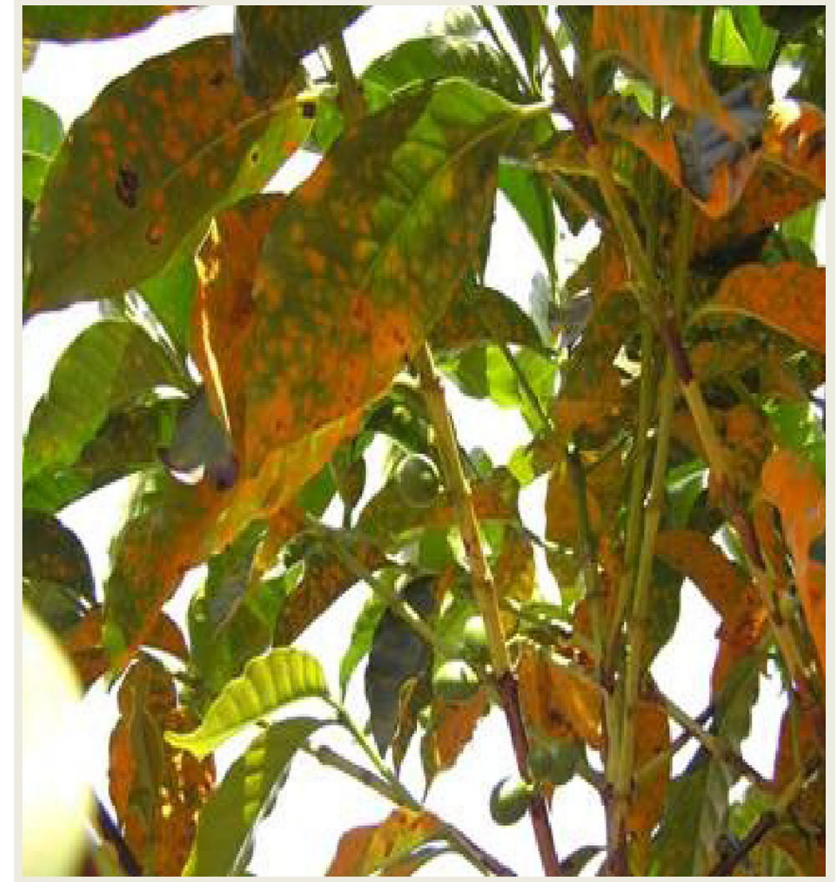

Fig. 3 Symptoms of Coffee Leaf Rust (Hemileia vastatrix) on coffee leaves

uredospores on the leaf surface; infections are rarely found on young stems and fruit. Appressoria are produced at the end of the germ tubes and entry is made into the substomatal cavity (Waller et al. 2007). Within 24-48 h, infection is completed. The leaf is then colonized and sporulation occurs through stomata. One lesion produces $4-6$ spore crops over a $3-5$ month period releasing $300-400,000$ spores. The presence of free water is required for infection to be completed. Loss of moisture after germination has been initiated inhibits the whole infection process.

The fungus is probably of East African origin (Waller et al. 2007) and is likely to have coevolved with coffee. CLR was first reported in Kenya in 1861, and by the 1920s it was found widely across much of Africa and Asia. It now occurs in all coffee growing regions globally.

\section{Impact}

As yields declined in the Old World, coffee cultivation (particularly that of arabica coffee) moved to the Western Hemisphere and countries of Latin America became the world's largest producers of coffee. Production was good partly because CLR was absent and the pest was successfully excluded for many decades. Unfortunately, in the 1970s, CLR was introduced into Brazil and spread rapidly through the coffee-growing areas at a rate of around $500 \mathrm{~km} /$ year, so that by 1975 the disease had reached all coffee areas. Possibly the uredospores could have been carried by upper air currents from Africa to Brazil, but it is more likely that human agency 
was involved (Waller et al. 2007). The spores could have been easily carried on luggage, people, plants, or airplanes that continuously move between the continents.

Eradication failed, the pest spread throughout coffee-growing areas, moving into Colombia and Central America; on-going management was initiated. However, recently, outbreaks were reported from 13 countries in Central America and the ICO states "The current epidemic of coffee leaf rust affecting all countries of the region with a $53 \%$ incidence is the worst seen since this pest appeared in Central America in 1976". See http://www.ico.org/.

In addition to yield loss from CLR, much of the coffee growing in the severely affected areas was stumped (pruned) to encourage fresh growth although it is highly unlikely such action will have much effect other than to suppress production for a longer period of time. Amy Angel from the Salvadoran Foundation for Economic and Social Development quoted in Baker (2014) estimated a decline in total export value for the affected countries from about US\$3.4 billion in 2011/12 to just US\$ 1.6 billion in 2013/14.

So why did this Central American outbreak occur? The pattern of the outbreak is complex and there was no major weather event that preceded it, unlike the outbreak in Colombia in 2008. Higher minimum temperatures including at altitude, coupled with lower than average and intermittent rains in affected countries could have contributed (Baker 2014). Some producers suspect a new aggressive race of rust is present but Avelino (2013) considered the problem in Costa Rica to be more about some unusual climatic conditions and pest management. Farmers did not apply chemical measures earlier enough and they were caught out by the unusually early attack but some producers have disputed this (Baker 2014). Nevertheless, with average fungicide/ha/year costing approximately $\$ 250$, farmers will delay spraying until they see it is needed (a just in time approach) and perhaps recently this strategy has not been appropriate.

\section{Management}

Resistant coffee material is available in Latin America. Colombia recovered from its own rust outbreak in 2008 and this was linked to an active policy of a massive programme of replanting resistant varieties which were available thanks to decades of sustained investment in research by their Coffee Federation. This came with a substantial cost - the Colombian Government is reported to have spent over a billion dollars on coffee since 2010 and breeding for resistance against this pest has proved difficult in the past due to the evolution of new races of the pest. The multiline approach as adopted in Colombia (Castillo 1989). where a range of different resistance genotypes are deployed, can reduce the epidemiological potential of the pest and is a possible strategy for managing this disease. Yet resistant material can have certain agronomic disadvantages and has not been favoured by roasters due to poor cupping quality and hence, not favoured by the farmers who could not get as good a price for their crop. The Castillo variety in Colombia seems to be an exception, having resistance coupled with some quality attributes and does seem to be favoured by some roasters. Chemical control can also be effective in management but has to be applied promptly at the start of the outbreak. Cultural practices such as reducing shade and reducing planting density to maximise drying after rain so reducing spore germination, are also advocated (Baker 2014).

\section{Case study 2 - coffee wilt disease in Africa}

Another example of re-emergence is Coffee Wilt Disease (CWD) in Africa which is causing significant yield losses e.g. $77 \%$ loss of robusta yields in Uganda (Hakiza et al. 2009). CWD is of particular significance because unlike many other coffee pests, it kills the trees and the farmer, who is often unable to replace his crop easily, faces major income shortfalls.

CWD, also called Tracheomycosis, is caused by Fusarium xylarioides (sexual form, Gibberella xylarioides) and is a vascular pest. The fungus invades the coffee tree and colonises the xylem system. Colonization of the vascular system induces host responses which disrupt water conduction and this is manifested as wilting and desiccation of leaves followed by defoliation, and die-back of affected branches. Symptoms may appear at any stage of crop growth and the rate at which they develop varies. Once affected, death of the plant is inevitable (Fig. 4) and in mature trees, usually occurs between three and fifteen months from first appearance of symptoms. Young plants may be killed within a matter of a few weeks of infection. Other external symptoms include the swelling of the trunk and the appearance of vertical or spiralling cracks in the bark of mature trees. Small blackish-brown perithecia (sexual stage) of the fungus, similar in appearance to dark soil particles, may be produced in the cracks of the bark. Characteristic bluish-black staining of the wood can be observed directly beneath the bark. For details see Flood (2009).

\section{Impact}

First observed in 1927 in Coffee excelsa, near Bangui in the Central African Republic (Figueres 1940). by 1945 the pest had destroyed most of the country's Coffea excelsa plantations. Later the pest was found on other coffee species (C. canephora and C. neo-Arnoldiana) in the Central African Republic and was reported in several other countries in West and Central Africa around the 1930s and 1940s. Over $50 \%$ of the coffee producing areas were destroyed in both Côte d'Ivoire and in DRC, and the Kouillou line of robusta was completely wiped out in Cote d'Ivoire. In Ethiopia, symptoms similar to those of CWD were documented on Coffea 


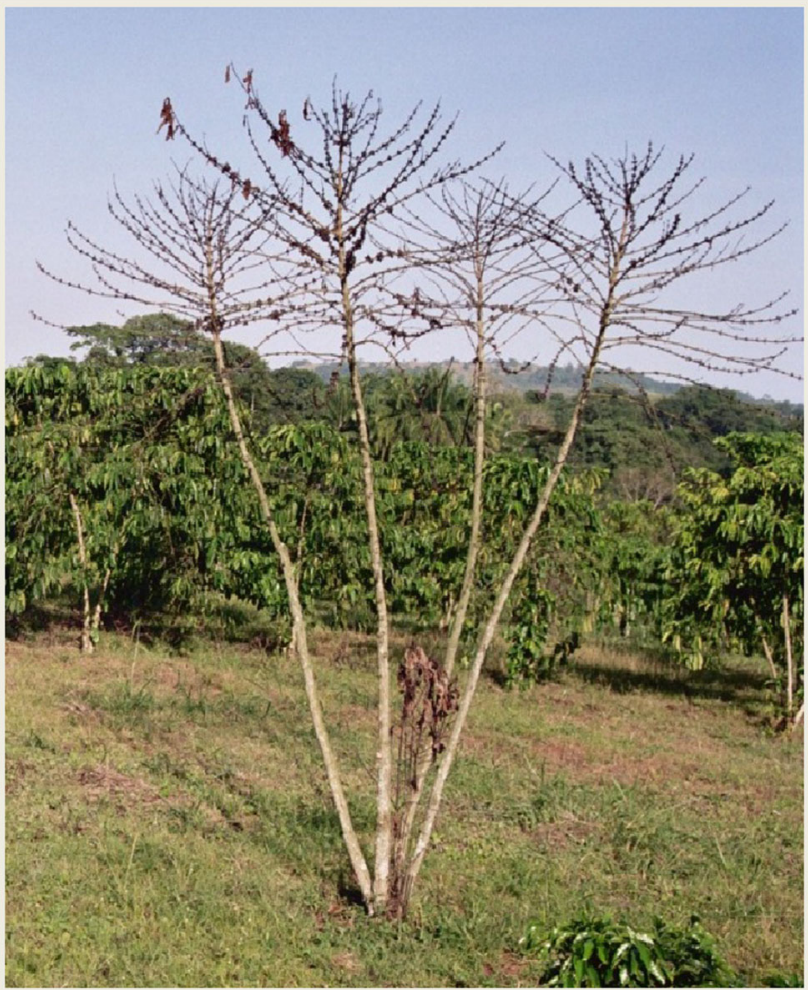

Fig. 4 Symptoms of Coffee Wilt Disease (Fusarium xylarioides) on robusta coffee in Uganda

arabica for the first time by Stewart (1957). A detailed account of the historical spread of the pest is given in Flood (2009).

At an international conference held in 1956, recommendations were made for a management programme to include a) systematic sanitation over vast areas, where affected coffee plants were to be uprooted and destroyed, b) where possible, to relocate coffee production to new locations, and c) replant with resistant germplasm. Implementation of these recommendations reduced the impact of CWD and literature produced during the 1970s and 1980s referred to this as a minor disease of little importance for arabica and robusta coffee production.

However, in remote areas of DRC, the disease continued to be observed, especially around abandoned plantations in the North East of the country. As early as the 1970s, farmers in Aketi (76 km from Isiro) had observed the pest in abandoned plantations. Throughout the 1980s, reports persisted of a wilt-like disease affecting coffee around the town of Isiro (Flood 1996) and surveys were conducted but these reports failed to come to the attention of national governments and the wider plant health community. It was only in 1995, when CABI's diagnostic laboratory received samples of diseased coffee plants from the Managing Director of Esco Zaire sprl (Mr Philip Betts) that Fusarium xylarioides was isolated. A survey was undertaken in DRC and an independent report on the nature and extent of the problem was prepared (Flood 1996). Unfortunately, the only recommendations available in the 1990s was similar to the 1950s - sanitation i.e. uprooting and burning coupled with long term breeding programmes. Sanitation was being conducted on plantations but CWD was spreading faster than plantation workers could undertake the work. For smallholders, removal of very old coffee bushes using hand tools was impossible; even where a plant had been dead for a year or more, its root system was virtually impossible to excavate.

A similar survey and report was prepared for Uganda (Flood 1997). It had also been noted in Uganda that the disease was only affecting robusta coffee; arabica coffee was not affected in Central Africa although CWD has continued to be a problem in Ethiopia on C. arabica. The Uganda government became so concerned about CWD that they asked for international assistance which eventually led to the establishment of the Regional Coffee Wilt Programme (RCWP). For details of the spread in Uganda, the establishment of the RCWP and its achievements see chapters in Flood (2009).

It was estimated that over 1 billion $\$$ have been lost from CWD (up to 2009) due to both direct losses from reduced coffee production and in costs incurred in trying to manage the disease (Phiri and Baker 2009).

\section{Management}

As part of the RCWP, participatory trials on CWD management were undertaken so that farmers could search for ways of reducing the impact. The effect of wounding coffee trees on increasing CWD incidence was quickly appreciated. Wounding often resulted from weeding with machetes. Other measures included avoiding cross contamination of healthy trees by sterilization of pruning tools. Participatory trials also helped raise awareness of CWD across the region so producers, extension workers and researchers were able to quickly recognise the symptoms. Extensive training of farmers and of extensionists (as trainers) in participating countries using the Farmer Field School (FFS) approach was adapted for coffee. An estimated 5 million producers were trained in CWD recognition and management. Mass communication methods such as print materials and use of radio and TV were also used to alert producers. Farmers in affected countries are now much more familiar with CWD and its management. Breeding for resistance remains the best option for management of CWD and, in Uganda, several resistant genotypes have been selected and multiplied for distribution to farmers. Further details of management approaches are given in Flood (2009).

\section{Summing up policy perspectives on outbreaks of established pests}

The re-emergence of CWD as a major production constraint for coffee production in several African countries, and the 
outbreak of CLR in Central America, illustrate how well known and established pests can still cause major and unexpected problems, particularly if there has been inadequate investment. Around half of employment in developing countries is in the agricultural sector and, for the least developed countries, around $75 \%$ of people are engaged in agriculture as their primary activity (Cheong et al. 2013). Yet investment in agriculture in some countries has declined (Flood 2010) leading to problems of lack of capacity to detect and respond to upsurges of established pests.

In Colombia, where sustained investment in research has allowed development and distribution of more resistant materials, the CLR outbreak in 2008 had less impact. Nevertheless, development of more resistant material is a significant undertaking. In addition to the devastated farms in Central America, approximately $40 \%$ of the total area remains planted with susceptible varieties and approximately $70 \%$ of the trees are 20 years and older. There is thus an urgent need to renovate farms with resistant varieties and this requires a major initiative on 'planting material production' as current sources are inadequate. It will take several years and much investment for coffee to begin generating significant revenues again. Farmers who choose to rehabilitate and/or renovate their farms will need financial and technical assistance to endure the three-to-five-year income gap. Diversification of income beyond coffee, including both agricultural and off-farm sources of income is being advocated (International Coffee Leaf Rust Summit 2013).

Longer term, a comprehensive analysis of the feasibility of coffee growing in Central America, the risks, costs, rewards and alternatives has been advocated (International Coffee Leaf Rust Summit 2013). A coffee variety development programme should be established in Central America to supply the region with a steady supply of varieties for direct use or pre-breeding materials for an emerging coffee seed industry. Other strategies such as a bio-control programme should also be investigated as part of an integrated approach to management.

Both case studies also highlight the danger of having no early warning and response system. Local extension workers in North East DRC knew a coffee pest was present in the mid to late 1980s but lack of plant health infrastructure meant nothing was done to manage the problem. This lessened probability of successful management, and the pest continued to spread into Uganda and into Tanzania. The International Plant Protection Convention has a tool (Phytosanitary Capacity Evaluation, PCE) for assessing the needs of plant health systems and infrastructure, and is making capacity development resources available through a portal (www.phytosanitary.info).

In Central America, as soon as conducive conditions arose for CLR, farmers needed to be alerted. Any system must be capable of sending warnings to producers about pest build up and timing of interventions. It is highly likely that a failure to apply inputs early enough contributed to the scale of the outbreak in Central America. To try to prevent similar outbreaks occurring in the future, an early warning system should be established to monitor predictive variables such as pest incidence, rainfall and temperature. A study is also needed to seek available meteorological data to try to define as precisely as possible the climatic conditions before and during the 2012 outbreak to best provide macro-predictive capability.

Linked to weather-related early warning systems, weather-indexed micro insurance for crop inputs is already developing (Hazell et al. 2010). Loss assessment is impossible for large numbers of small enterprises, so automatic weather stations provide an index for an area, on the basis of which insurance is paid or not. A similar approach might be possible for specific pests, provided a suitable method for assessing the losses over a wide area could be developed.

Investment in farmer training and awareness and training of extension workers is also needed in many developing countries especially with regard to diagnostics and use of good agricultural practices. A system of reliable forecasting and early warning has to be coupled with raised awareness of Good Agricultural Practice (GAP) for producers. This may include reduced planting densities to assist leaf drying and reduce spore germination and to allow easier access for crop husbandry including spraying appropriate pesticides where necessary. Producer training and education on use and application of pesticides, based on a good understanding of the biology of the pest, are also priorities.

\section{Risks relating to management efforts}

The final category of risks considered are those linked with management efforts and, specifically, the risk from using agrochemicals. This includes health risks to those applying the chemicals, risks of aggravating pest problems, and risks associated with markets such as exceeding maximum residue levels or failing to comply with other regulatory requirements.

Health concerns include contamination of non-target food crops whilst the farmer is spraying their commodity crop, as well as contamination of the farmer during spraying due to faulty or badly maintained equipment. Many farmers in developing countries do not wear recommended protective clothing because it is too expensive and/or the climate may makes it very uncomfortable. A UN report recently highlighted the potential cost of pesticide-related illnesses in Sub Saharan Africa from 2005 to 2020 could reach $\$ 90$ bn (UNEP 2012). Although pesticide use in Africa is still low on average, where crops are grown for market and pesticide use is perceived to offer a financial return or at least an insurance against pest damage, use is much more common. Insecticide use in cotton, for example, has been notoriously heavy (around $15 \%$ of global pesticide use), including the use of older broad spectrum and cheaper products such as 
endosulfan. Many such pesticides are now no longer registered in many developing countries and newer, more pest-specific pesticides are being marketed there but these tend to be more costly. There are no comprehensive data on pesticide poisonings in Africa, but where studies have been done, short and long term illnesses as well as fatalities are frequently found (WAHSA 2004) and pesticide poisoning in developing country commodity production may be much more widespread than reported.

The use of pesticides can aggravate pest problems in two ways. Natural enemies of either the target or other pests may be depleted, releasing pests from natural control and leading to outbreaks. Conway (1971) showed that outbreaks of pests in Malaysian cocoa were due to pesticide spraying, and cessation of spraying allowed the natural enemies to build up again and restore natural control. This is the basis for integrated pest management. Excessive spraying may also cause resistance in the target pest. In West Africa several cotton pests have developed resistance, including Helicoverpa armijera to pyrethroids (Martin et al. 2005; Achaleke and Brévault 2010) and Bemisia tabaci to pyrethroids, organophosphates and neonicotinoids (Houndété et al. 2010).

Market access problems can be caused by pesticide residues and use of non-registered pesticides which lead to risks of consignments being intercepted, resulting in costly treatment or even rejection due to exceeding a maximum residue level (Buurma et al. 2001; Jaffee and Henson 2005). This impacts on exporting countries' trade and on producer livelihoods. Also, following food safety scares within consuming countries e.g. in Europe, food companies and consumers are concerned about the safety of their food. The case study below illustrates the effects of policy decisions of the public and private sector stakeholders on progress with addressing safety concerns around pesticide use in cocoa production in West Africa and South East Asia.

\section{Case study: food safety in cocoa in west Africa and South East Asia}

West Africa produces approximately $75 \%$ of the world's cocoa, and accounts for more than $85 \%$ of the cocoa used by the European cocoa industry. Within the European Union (EU), regulation 396/2005 defines the maximum levels of residues (MRLs) permitted in food and feedstuffs in the EU and came into force on 1 September 2008 with significant implications for global trade. For the first time, MRLs were applied to commodities and raw materials imported to the EU as well as to those produced in the EU. Further, this regulation harmonised the accepted MRLs for the whole EU whereas previously, individual EU Member States could set their own MRLs.

The cocoa and chocolate industry as a whole welcomed the harmonization of EU pesticide residue legislation as it further strengthened measures designed to protect consumers and the environment. In addition, use of pesticides according to good agricultural practice (GAP) would have benefits in safeguarding the health and welfare of those exposed to pesticides in supplying countries and by helping to protect their local environment. However, the new EU legislation also presented a considerable challenge to producing countries e.g. in West African countries which are heavily dependent on cocoa for income generation. Failure to comply with the EU requirements could have severe consequences, and this was quickly recognised by the cocoa industry.

A two year collaborative project was initiated with funding from The Netherlands Ministry of Agriculture, Nature and Food Quality and administered by ECA/CAOBISCO Secretariat which had two primary objectives. Firstly, information was gathered from various cocoa stakeholder groups on the supply and use of agrochemicals along the commodity supply chain in each country. The surveys were co-ordinated and conducted by scientific teams from four internationally recognised and respected cocoa research institutes within West Africa. Secondly, building on the findings of stage one, awareness was raised of current issues and potential problems with respect to agrochemical supply and use and activities initiated to help promote and implement better agrochemical practice (Rutherford et al. 2009). A similar approach was undertaken in Indonesia (Fig. 5). Further capacity building projects have been conducted in West Africa with funding from the STDF under the auspices of the ICCO and substantial progress made on the training of law enforcement agents on anti-counterfeit measures on pesticides, and on cross-border trade of illegal pesticides and other agrochemical products (see http://www.icco.org/sites/sps/). A similar project led by $\mathrm{CABI}$ is on-going in SE Asia with training modules on good agricultural practices (GAP) and Good Warehousing Practices (GWP) being developed and training programmes for trainers and farmers conducted. Much of the basis for the capacity building involves a move towards an IPM approach (see www.cocoasafe.org).

By recognising the challenges, engaging with policy makers and taking action to reduce the probability, the cocoa industry as a whole has been able to avoid serious market access problems due to pesticide residues.

\section{Summing up policy perspectives for risks associated with management}

Following various food scandals in consuming countries, consumers are very aware of food safety, and their concerns have fed through to policy makers who have enacted legislation to protect their electorates. The legislation also had positive effects for the environment and for producer health but this legislation could have impacted on exporting countries' trade 
Fig. 5 Interviewing farmers about pesticide usage in cocoa supply chains inIndonesia

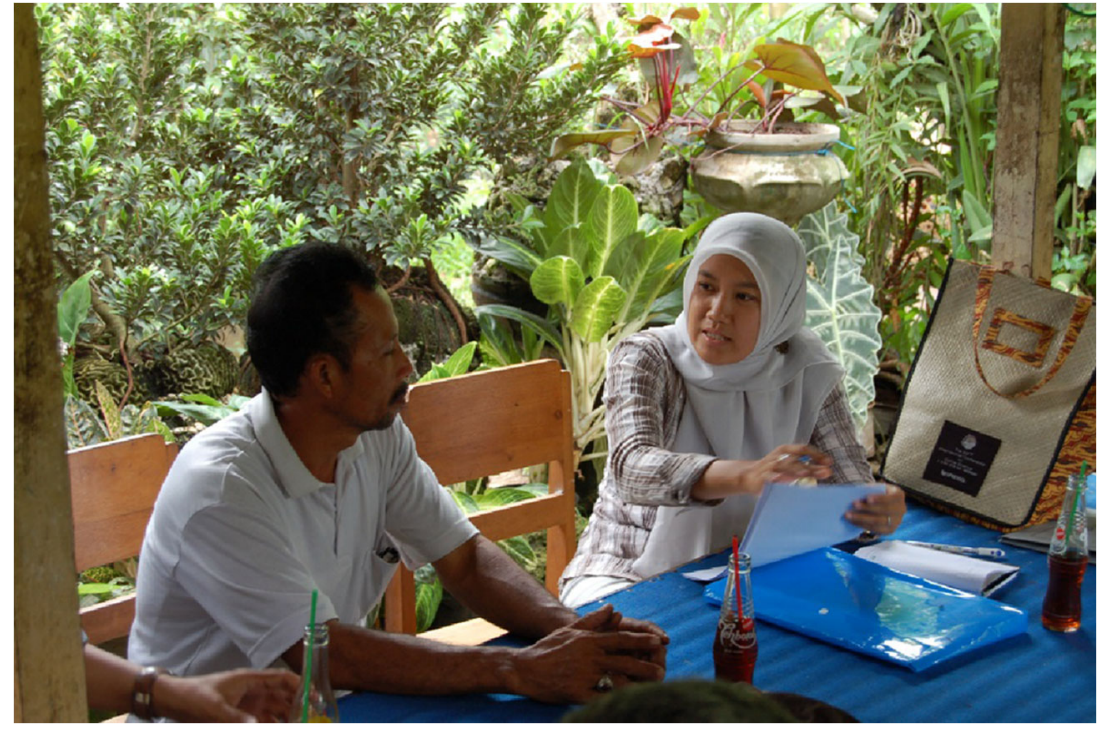

(rejection of commodity consignments) as well as having a negative impact on the livelihoods of individual commodity producers. The recognition of the wider issues and challenges by the cocoa industry (as a whole) led to a risk management approach involving capacity building about pesticide usage and raising awareness of food safety concerns through the cocoa supply chain, and this has considerably reduced the risk. Food safety concerns have been one of the drivers towards better traceability in supply chains including those of the commodities discussed here, and the establishment of industry and private standards plus certification schemes, such as Rainforest Alliance, Utz and Fairtrade, have also contributed to improved traceability as well as enhancing overall environmental and social sustainability criteria in supply chains. Reduced use of pesticides and more appropriate application is a positive outcome for all supply chain stakeholders.

However, such legislation can constrain options for managing pests and does potentially increase the risks of pest losses in production. An appropriate policy response is therefore to promote the development and registration of pest management products of lower risk, which will allow effective management of risks to production, as well as minimise the risks of breaching importing countries' food safety requirements. A range of obvious and hidden price and non-price factors may encourage pesticide use (Waibel 1991). such as providing tax exemption on agricultural inputs and this can have the effect of reducing development of lower risk management products. Also, registration procedures that require the same level of testing for high risk products such as chemical pesticides as for lower risk products such as biopesticides may, unintentionally, reduce biopesticide development as well as promoting products which are less specific and thus, have a larger market (Sundh and Goettel 2013).

\section{Conclusions}

Three areas of pest risks with varying likelihoods and consequences have been presented. The probability of pest introductions is increasing, and in some cases this could have catastrophic consequences such as for cocoa production in West Africa, should Witches' broom or Frosty Pod be introduced from Latin America. Eradication is rarely successful so exclusion is the better option and is much less costly than attempts at eradication or ongoing management. Policy decisions should adopt a more pro-active approach to planning - a biosecurity approach - whereby pathways of likely introduction are identified and contingency plans designed ahead of any introduction, including the allocation of resources. In many developing countries where commodities are produced, such contingency planning is still uncommon.

With regard to outbreaks of established pests, the probability will almost certainly be affected by climate change. Such outbreaks can have far reaching consequences for producer livelihoods and the countries concerned as exemplified here by two pests of coffee. Forecasting future severity of individual pests is probably not feasible, but with increased knowledge of pest population dynamics, scope exists for short term forecasting, coupled with early warning and detection systems. This will require investment in research and extension for the agricultural sector. As well as mitigating risk, it can be transferred through insurance, and weather-indexed micro-insurance schemes for crop inputs are already becoming more widespread.

The risks associated with management of pests are more varied. As production intensifies and becomes more market oriented, the risks of pesticide misuse increase, and in developing countries with limited capacity to enforce regulations, this can have serious consequences for human health and the environment. However, strict food safety regulations in 
developed country markets can have a positive impact in developing countries, once the commodity network actors have recognised and decided to act to reduce the risks to market access and reputation, as shown by the cocoa case study. Policy needs to be focussed on raising awareness of safety concerns through the supply chain from the producer to the consumer, including enhancing traceability. Improved capacity building and training for the management of pests using agrochemicals is required. Policy should promote adherence to the International Code of Conduct on Pesticide Management (FAO 2013b). and encourage the development and registration of lower risk pest management products.

\section{Abbreviations}

CAOBISCO: Association of the Chocolate, Biscuits and Confectionery; ECA: European Cocoa Association; FAO : Food and Agriculture Organization; ICO: International Coffee Organization; ICCO: International Cocoa and Chocolate Organization; ILO: International Labour Organization; ITC: International Trade Centre; STDF: Standard and Trade Development Facility; UNCTAD: United Nations Conference on Trade and Development; UNEP: United Nations Environment Programme; WAHSA: Work and Health in Southern Africa; WFP: World Food Programme.

Acknowledgments The authors would like to acknowledge Dr. Peter Baker and Dr. Jayne Crozier for useful discussions. This paper was presented at a conference sponsored by the OECD's Co-operative Research Programme on Biological Resource Management for Sustainable Agricultural Systems whose financial support made it possible for most of the invited speakers to participate. The opinions expressed and arguments employed in this publication are the sole responsibility of the authors and do not necessarily reflect those of the OECD or of the governments of its Member countries.

Open Access This article is distributed under the terms of the Creative Commons Attribution 4.0 International License (http://creativecommons. org/licenses/by/4.0/), which permits unrestricted use, distribution, and reproduction in any medium, provided you give appropriate credit to the original author(s) and the source, provide a link to the Creative Commons license, and indicate if changes were made.

\section{References}

Achaleke, J., \& Brévault, T. (2010). Inheritance and stability of pyrethroid resistance in the cotton bollworm helicoverpa armigera (Lepidoptera: noctuidae) in central Africa. Pest Management Science, 66, 137-141. doi:10.1002/ps.1843.

Avelino J 2013 Tooling up for climate change. Presentation at ICO 50th Anniversary Meeting 9-12th September 2013. Belo Horizonte, Brazil http://issuu.com/coffeeandclimate/docs/the coffee rust crisis_in_central_a
Baker PS (2014) The 'big rust': an up Date on the coffee leaf rust situation. In coffee \& cocoa international. 2014 p 37-39.

Bissesser, S. (2011). Preventing the entry of moniliophthora roreri (causal agent of frosty pod rot of cocoa) into Trinidad and Tobago. In Output as part of a UNEP/GEF project on "mitigating the threats of invasive alien species in the insular Caribbean" in collaboration with CABI and the ministry of food production. Trinidad \&: Tobago.

Buurma, J. S., Mengelers, M. J. B., Smelt, A. J., \& Muller, E. (2001). Developing countries and products affected by setting new maximum residue limits of pesticides in the EU. The Hague: Agricultural Economics Research Institute.

Castillo ZJ (1989) Breeding for rust resistance in Colombia. In: Kushalappa AC Eskes, A.B. (eds) Coffee rust: epidemiology, Resistance and Management. CRC Press, Boca Raton, Florida, pp. 307-316.

Cheong D, Jansen M, Peters R (2013) Shared Harvests: Agriculture, Trade and Employment. ILO and UNCTAD, 2013. Geneva. ISBN: 978-92-2-126812-3 (print); ISBN: 978-92-2-126813-0 (web pdf)

Conway, G. R. (1971). Pests of cocoa in Sabah and their control : (with a list of the cocoa Fauna) (125p). Sabah, Malaysia: Kementerian Pertanian dan Perikanan.

End MJ, Daymond AJ, Hadley P (2014) Technical guidelines for the safe movement of cacao germplasm (Revised from the FAO/IPGRI Technical Guidelines No. 20). Second update August 2014. Global cacao genetic resources network (CacaoNet), Bioversity International, Montpellier, France. ISBN 978-92-9043-987-5

Evans, H. C. (1981). Pod rot of cacao caused by moniliophthora (monilia) roreri. Phytopathological Papers, 24, 1-44.

FAO (1997). International standards for phytosanitary measures, ISPM 6 $(9 p)$. FAO, Rome: Guidelines for surveillance.

FAO (2009). International Standards for Phytosanitary Measures No. 5 Glossary of Phytosanitary Terms. Rome: Food and Agriculture Organization.

FAO (2013a). International standards for phytosanitary measures, ISPM 11 , pest risk analysis for quarantine pests (36p). Rome: FAO.

FAO (2013b). International code of conduct on the management of pesticides. Rome: Food and Agriculture Organization.

Figueres, R. (1940). Sur une maladie très grave du caféier en oubangui. Ministère des Colonies, Paris, France: Rapport.

Flood, J. (1996). A study of the tracheomycosis or vascular wilt disease of coffee in Zaire. Report presented to Zairean Coffee Organisation (OZACAF). August 1996. 13 pp.

Flood, J. (1997). Tracheomycosis or vascular wilt disease of coffee in Uganda. Report presented to Ugandan Coffee Development Authority (UCDA), Uganda. January 1997. 12 pp.

Flood J (2009) Coffee Wilt Disease. 200 pages. CABI. UK ISBN:978-1$84593-641-9$

Flood, J. (2010). The importance of plant health to food security. Food Security, 2(3), 215-231.

Flood J, Murphy R (2004) Cocoa futures- a source book for important issues facing the cocoa and chocolate industry. CABI Commodities press. ISBN 958-96554-2-5.

Fraser, G. (in press) Biosecurity and food security-effective mechanisms for public-private partnerships. Food Security (this volume)

Gilmour M (2004) Towards sustainable cocoa production. In Flood J, Murphy R (eds) Cocoa Futures- a source book for important issues facing the cocoa and chocolate industry. CABI Commodities press, pp150-161, ISBN 958-96554-2-5.

Hakiza, G. J., Kyetere, D. T., Musoli, P., Wetala, P., Njuki, J., Kucel, P., et al. (2009). Coffee wilt disease in Uganda. In J. Flood (Ed.), Coffee wilt disease (pp. 28-49) ISBN:978-1-84593-641-9. UK: CABI

Hazell, P., Anderson, J., Balzer, N., Hastrup Clemmensen, A., Hess, U., \& Rispoli, F. (2010). The potential for scale and sustainability in weather index insurance for agriculture and rural livelihoods. IFAD and WFP: Water. Rome. 
Houndété, T. A., Kétoh, G. K., Hema, O. S. A., Brévault, T., Glitho, I. A., \& Martin, T. (2010). Insecticide resistance in field populations of bemisia tabaci (hemiptera: aleyrodidae) in west Africa. Pest Management Science, 66(11), 11811185. doi:10.1002/ps.2008.

International Coffee Leaf Rust Summit (2013). Report of the First International Coffee Leaf Rust Summit. World Coffee Research/ Promacafe. Guatemala, April 18-20, 2013. www.promecafe.org/ web/images/stories/coffeerustsummit-ingles.pdf

Jaffee, S. M., \& Henson, S. (2005). Agro-food exports from developing countries: the challenges posed by standards. Chapter 6. In M. Ataman Akson, \& J. C. Beghin (Eds.), Global agricultural trade and developing countries (pp. 91-114). Washington DC: The World Bank.

Koblenz, G. D. (2010). Biosecurity reconsidered: calibrating biological threats and responses. International Security, 34(4), 96-132.

MacLeod, A., Pautasso, M., Jeger, M. J., \& Haines-Young, R. (2010). Evolution of the international regulation of plant pests and challenges for future plant health. Food Security, 2(1), 49-70.

Martin, T., Ochou, G., Djihinto, A., Traore, D., Togola, M., Vassal, J., et al. (2005). Controlling an insecticide-resistant bollworm in west Africa. Agriculture, Ecosystems \& Environment, 107, 409-411. doi:10.1016/j.agee.2004.11.006.

Martins, D. S. A. (2006). Administração rural e os testes de competência administrativa. Urucuça, Bahia, Brasil: In Agenda Técnica CEPLAC.

Pereira JL (2012) Integrated management of witches' broom. In Congresso Brasileiro do Cacau Ilhéus, Bahia, 11-14th

Pereira, J. L., Ram, A., de Figueiredo, J. M., \& de Almeida, L. C. C. (1990). The first occurrence of witches' broom disease in the principal cocoa growing region of Brazil. Tropical Agriculture, 67, 188189.

Pereira, J. L., de Almeida, L. C. C., \& de Santos, S. M. (1996). Witches' broom disease of cocoa in Bahia: attempts at eradication and containment. Crop Protection, 15(8), 74.

Perrings, C., Williamson, M., \& Dalmazzone, S. (2000). The economics of biological invasions. Cheltenham, UK: Edward Elgar Publishing Ltd.

Phillips-Mora, W., Aime, M. C., \& Wilkinson, M. J. (2007). Biodiversity and biogeography of the cacao (theobroma cacao) pathogen moniliophthora roreri in tropical America. Plant Pathology, 56, 911-922.

Phillips-Mora, W., Castillo, J., Arciniegas, A., Mata, A., Sánchez, A., Leandro, M., et al. (2009). Overcoming the main limiting factors of cacao production in Central America through the use of improved clones developed at CATIE (pp. 16-21). Bali, Indonesia: Proceedings of the 16th International Cocoa Research Conference, COPAL.

Phiri, N., \& Baker, P. S. (2009). Coffee wilt disease in Africa; a synthesis of the work for the regional coffee wilt programme (RCWP). Final Technical Report: CABI 200 pages.

Pimentel, D. (2011). Biological invasions: economic and environmental costs of alien plant, animal, and microbe species (2nd ed., ). Boca Raton: CRC Press.

Rutherford MA, Nyassé S, N'Guessan K F, Agbeniyi, SO, Baah F (2009). Cocoa production and trade in West Africa- meeting the needs of new EU pesticide legislation. Proceedings of the 16th international cocoa research conference. COPAL, Bali, Indonesia 2009 pp903908

Stewart, R. B. (1957). Some diseases occurring in kaffa province, Ethiopia. In: imperial Ethiopian college of agriculture and mechanical arts (pp. 15-16). Ethiopia: Alemaya.
Sundh, I., \& Goettel, M. S. (2013). Regulating biocontrol agents: a historical perspective and a critical examination comparing microbial and microbial agents. BioControl, 58, 575-593.

UNEP (2012) Factsheet on Harmful substances and hazardous waste. 8 pages http://www.unep.org/hazardoussubstances/

WAHSA. (2004). Acute pesticide poisoning and the need for national surveillance systems. The case example of Tanzania. WAHSA Policy Brief. Cape Town, Dar es Salaam: Work and Health in Southern Africa (WAHSA). Retrieved from http://www.ncbi.nlm. nih.gov/pubmed/20058061.

Waibel, H. (1991). Pesticide subsidies in Southeast Asia. FAO Plant Protection Bulletin, 38(2), 111-120.

Waller JM, Bigger M, Hillocks RJ (2007). Coffee pests, diseases and their management. Wallingford, Oxfordshire: CABI. p. 171. ISBN 184593-129-7

Williamson, M., \& Fitter, A. (1996). The varying success of invaders. Ecology, 27(6), 1661-1666.

World Bank (2012). Supply chain risk assessment: cocoa in Ghana. World Bank: Washington.

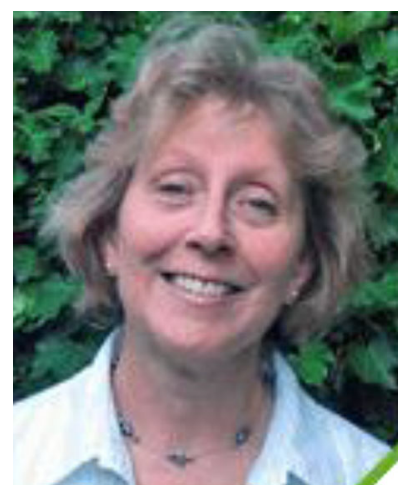

Dr Julie Flood is Senior Global Director for Trade \& Commodities in CABI. She has 30 years experience of working with tropical perennial crops. She spent 16 years in the UK academic system (Universities of Bristol and Bath) before moving to Papua New Guinea as Head of Plant Pathology at CCRI. She joined CABI in 1996 and moved to her current role in 2007. She oversees CABI's trade related projects improving management of pests/ diseases; increasing productivity through adoption of GAP (Good Agricultural Practice); improving market access for producers. A plant pathologist by training, she is increasingly interested in the wider aspects of plant health including impacts on food security, biosecurity and trade. She has over 100 publications and has edited three books.

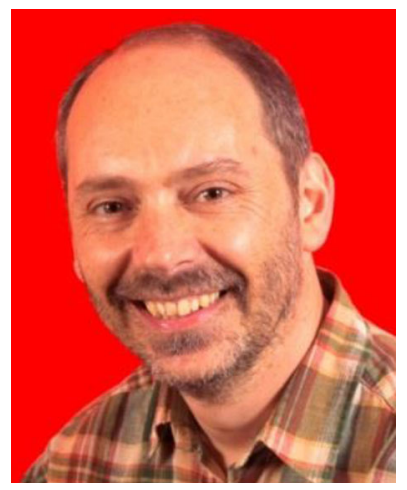

Roger Day is an entomologist, with a broad interest in plant health issues in relation to production and trade. He first worked in South-East Asia, developing control methods for the cocoa pod borer, but for over 20 years he has been based in Africa at CABI's regional centre in Nairobi, Kenya. Over the years he has become increasingly interested in how and why research gets used, and contributes to social and economic development. In the context of plant health and phytosanitary systems this touches on agricultural extension and communication, capacity development, regulation and policy. 